УДК 373.61

DOI: $10.31891 / 2307-5740-2021-300-6-11$

СКОРИК Г. І.

ORCID ID: 0000-0002-6637-7252 e-mail: gskoryk67@gmail.com НЕДОШИТКО А. А. ORCID ID: 0000-0001-9874-6182 e-mail: anhelina02@gmail.com

Національний університет «Львівська політехніка»

\title{
РОЗВИТОК СТАРТАПІВ В УКРАЇНІ: ПРОБЛЕМИ ТА ПЕРСПЕКТИВИ
}

\begin{abstract}
Проаналізовано стан ринку стартапів в україні, обгрунтовано його важливість для підвищення конкурентоспроможності національної економіки. Визначено головні проблеми в реалізації стартапів з урахуванням стадій ї реалізації та обгрунтовано, що головною з них є пошук джерел інвестиційних ресурсів. Визначено основні чинники, які впливають на інвестиційну привабливість стартапів. Доведено необхідність та основні напрямки державної підтримки стартапів.
\end{abstract}

Ключові слова: стартапи, стадія реалізації стартапу, інноваційна ідея, інвестування стартапів.

HALYNA SKORYK, ANHELINA NEDOSHYTKO

Lviv Polytechnic National University, Lviv

\section{STARTUP DEVELOPMENT IN UKRAINE: PROBLEMS AND PROSPECTS}

\begin{abstract}
The development of startups is a powerful factor in socio-economic progress. Ukraine has significant potential to create a new types of business, the introduction of production of goods and services that can satisfy changing and very diverse needs of society. Therefore, there is a need to analyze the features of implementation, the most important problems and startup's risks.

Ukraine has significant potential for the startup's development, which is confirmed by its high position in a world rankings. At the same time, the activity in the implementation of startup projects in different regions differs significantly. The most successful startups were analyzed and the spheres of their realization were determined. Almost all of them are related to the field of computers and information modern technologies (IT), which indicates about the prospects for the development of this industry in the Ukraine. There are highlighted the main stages of the startup: Seed and development; Startup stage; Establishment and growth; Expansion stage; Maturity. And also justified the most important problems that come up during these stages. Implementation of startups is complicated by this factors, such as: difficult financial position; lack of information support; unfavorable investment climate; low support from the government; insufficient level of knowledges in the field of business development. There were identified the factors that determine the investment attractions of startups the necessity and directions of country's support for startups are substantiated.

Ukraine has significant potential: highly qualified engineering resources, lots of cool ideas and enterprising people, who are ready to implement business innovations. However, only with the effective support from the government to the entrepreneurship in the field of innovation, financial support, effective system of protection of intellectual property rights, the development of appropriate regulatory framework, which will regulate legal relations in the startups' market and in the sphere of their investment, then Ukrainian startups projects will have significant potential to develop and growth.

Keywords: startups, startup implementation stage, an innovative idea, the startup investment.
\end{abstract}

\section{Постановка проблеми у загальному вигляді}

та їі зв'язок з важливими науковими чи практичними завданнями

Важливим завданням сучасного етапу соціально-економічного розвитку України є підвищення рівня конкурентоспроможності національного виробництва, насамперед, на засадах інноваційно-інвестиційної моделі. Особлива роль у цьому належить інноваціям, новим формам бізнесу і стартапам. Для того аби вирішити соціальні та економічні проблеми суспільства та окремих підприємств, державний апарат країни повинен шукати та застосовувати нові підходи до управління процесами створення нових послуг та розробки товарів, активізації державного та приватного підприємництва, пошуку інноваційних рішень. Україна має значний потенціал щодо створення нових видів бізнесу, форм підприємництва і впровадження виробництва товарів і послуг, здатних задовольнити мінливі і дуже різноманітні потреби суспільства. Актуальність дослідження полягає в тому, що розвиток стартапів є потужним фактором соціальноекономічного прогресу. Активність України у цьому процесі підтверджується іiі високою позицією у світових рейтингах. Проте на тлі успішних стартап-проєктів існує велика кількість неуспішних. Відтак виникає потреба проаналізувати особливості реалізації, найважливіші проблеми і ризики стартапів.

\section{Аналіз останніх досліджень і публікацій}

Зважаючи на актуальність розвитку інноваційного підприємництва в тому числі і шляхом стартапів, питання щодо їх суті, умов, перспектив і проблем реалізації досліджуються низкою українських та зарубіжних дослідників. Питання змістовного розуміння стартапу і умов його реалізації вивчаються в роботах Рудь Н.Т., Саліхова О.Б., Курченко О.О., Іванченко Н.О., Подскребко О.С., Сідлецької А.О., Яцкевич І.В. та ін. Не зважаючи на це, залишаються дискусійними питання розвитку стартапів, виявлення проблем, що стримують їх розвиток та пошуку джерел їх фінансування. 


\section{Формулювання цілей статті}

Сьогодні, в умовах стрімкого розвитку технологій, суспільство має можливості для розвитку штучного інтелекту, інтернет-торгівлі, активного провадження стартапів. Нагальними залишаються вирішення питань щодо впровадження та розвитку нових інвестиційних проектів. На шляху від самої задумки до реалізації вони проходять багато етапів та неодноразово зіштовхуються 3 великою кількістю проблем, які властиві українській економіці. Пошук методів вирішення проблем, що характерні для розробки і реалізації стартапів є заключним елементом ефективного розвитку їх ринку, створення, впровадження та просування нових видів бізнесу, насамперед, інноваційних.

У зв'язку із цим метою статті є аналіз розвитку стартапів в Україні та виявлення найважливіших проблем, що виникають на усіх стадіях їх реалізації.

\section{Виклад основного матеріалу}

10-30 роки XXI ст. називають «бумом», або «ерою» стартапів. Насамперед, це зумовлено стрімким розвитком сучасних технологій, робототехніки, технологій інтернет-речей, які щодня з'являються на світових ринках та змінюють одна одну. Згідно із законом зростання потреб ринок постійно потребує нових і креативних ідей, розробок, винаходів. Як наслідок, навіть провідні гіганти (Google, Facebook, Tesla, Apple) не завжди встигають задовольняти попит, що зростає. Це є головною причиною того, що бум інновацій не зупиняється. У зв'язку із цим особливе місце належить стартапам.

Стартапи є відносно новим явищем в українському бізнесі, що стрімко розвивається. Проте й досі термін «стартап» не закріплено в жодному законодавчому акті. Як наслідок цього часто виникають ситуації, що перешкоджають ефективному впровадженню задуманих проєктів.

За даними світового рейтингу Startup Ranking 2020 р. Україна займає 43 місце у світі за розвитком стартапів. Сьогодні у десятку розвинених стартап-країн входять: США (майже 70000 стартапів), Індія (11636 стартапів), Великобританія (5991 стартапів), Канада (3111 стартапів); Індонезія (2296 стартапів); Німеччина (2247 стартапів); Австралія (2096 стартапів); Франція (1541 стартапів); Іспанія (1385 стартапів); Бразилія (1164 стартапів). Україна представила світовому ринку лише 337 стартапів [1, 2] (рис. 1).

\section{Кількість стартапів}

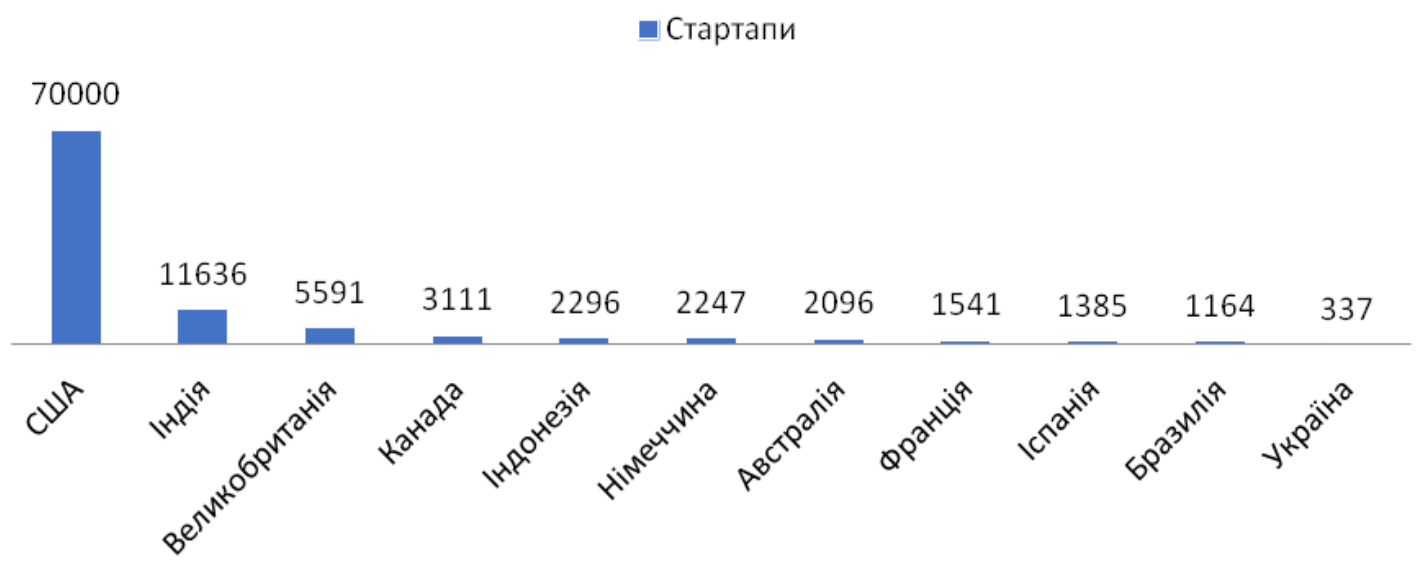

Рис. 1. Кількість стартапів у провідних країнах світу

Серед українських міст першим у рейтингу є Київ, який втративши свої позиції у 2020 році порівняно із попереднім роком на 16 пунктів, входить у топ-50 і залишається лідером 3 впровадження стартапів у сфері програмного забезпечення, маркетингу і продажу. До світового рейтингу увійшли такі міста, як Львів (255 місце), Одеса (394 місце), Харків (513 місце), Тернопіль (787 місце), Дніпро (883 місце). Слід підкреслити, що лише м. Львів покращило свій рейтинг на 99 позицій, тоді, як усі інші міста його дещо погіршили [3].

Якщо детально розглянути та проаналізувати топ 10 українських стартапів, то можна відмітити, що практично всі пов'язані зі сферою сучасних технологій (IT). Це вказує на перспективність розвитку даної галузі в Україні [2]. Застосування IT технологій забезпечує прибутковість діяльності компаній, сприяє виходу на міжнародний ринок, а також забезпечує підвищення рівня конкурентоспроможності вітчизняного виробництва. Створення сприятливих умов для розвитку стартапів залежить від функціонування венчурного ринку, який останнім часом активно формується.

Серед найбільш цікавих інноваційних ідей:

- SolarGaps - виготовлення жалюзі з сонячними панелями [4]; 
- Cardiomo - винахід, що може допомогти рятувати мільйони життів, попереджуючи людей про десятки захворювань, зокрема про хвороби серця [4];

- Grammarly - інтелектуальний онлайн-сервіс на основі штучного інтелекту для допомоги у написанні текстів англійською мовою, перевірки правильності, чіткості та тону повідомлення [5];

- Enjoy The Wood - виготовлення 3D-карт світу з дерева [6]; стилі [6].

- Jollylook - створення першої у світі фотокамери з переробленого картону та двох лінз у ретро-

У сучасній літературі не вщухають дискусії щодо етапів розвитку стартапів [7]. Зважаючи на це, вважаємо, що можна виокремити такі стадії їх реалізації:

\begin{tabular}{|l|l|}
\hline 1 & -Seed and development («Посів» та розвиток) \\
\hline 2 & -Startup stage (запуск) \\
\hline 4 & -Establishment and growth (становлення і зростання) \\
\hline 4 & - Expantion stage (розширення) \\
\hline & - Maturity (зрілість) \\
\hline
\end{tabular}

Рис. 2. Стадії реалізації стартапів

Початкова стадія - це фактично початок життєвого циклу бізнесу, навіть якщо стартап поки що офіційно не існує. Це стадія появи ідеї. Передбачається, що особа має власну бізнес-ідею та уже готова для того, щоб зробити перший крок у іiі реалізації. Але на даному етапі в першу чергу потрібно оцінити життєздатність стартапу. Одним із важливих завдань даної стадії є формування команди, яка об'єднує як однодумців, так і помічників. Також розробляється бізнес-модель, описуються основні етапи майбутнього розвитку, тестується та апробується прототип (лише у тому випадку, якщо він вже створений). Відповідно до теорії факторів виробництва, успіх стартапу залежить від підприємницького хисту, наявності капіталу, команди працівників та інших ресурсів. На цьому етапі також потрібне мінімальне фінансування (власні заощадження, кошти друзів, батьків тощо). Та найактуальнішим завданням залишається питання пошуку інвесторів, тому особлива роль у цьому належить бізнес-інкубаторам, акселераторам. Крім того участь у конкурсах чи менторська підтримка дадуть важливий досвід та навички, які стануть у нагоді на подальших етапах розвитку. На першій стадії реалізації стартапу головними проблемами є: помилки постановки завдань, складність пошуку і залучення інвесторів, недостатній рівень знань і досвіду у розвитку бізнесу.

Стадія «Startup stage» включає в себе оформлення ідеї і безпосередньо запуск стартапу. Тобто налаштування покрокової системи просування ідеї та пошук подальшого фінансування. Як наслідок, відбувається активна організація виробництва та підготовка продукту на ринок. На даному етапі розвитку стартапу вже оформлено особу-підприємця, створена команда (де функції кожного уже розподілені), зроблено перші проби виходу реклами. Більшість іноземних підприємців вважає, що помилки, які вчинені на даному етапі, вплинуть на подальший розвиток проекту загалом.

3 метою фінансування стартапу на даному етапі ідеальним варіантом є пошук бізнес-ангела людини, яка спрогнозує перспективність проекту і виявить бажання інвестувати власні кошти у його впровадження. Ще одним джерелом фінансування є краудфандінг (народне фінансування). Стартапер «купує» місце на цій платформі або ж орендує іiі на певний час, поки не назбирає необхідну суму коштів. Головною проблемою для успішного проходження даної стадії $є$ висока ймовірність нераціонального розподілу завдань та функцій між членами команди, що може призвести до тимчасових непорозумінь, які можуть перерости у проблеми розвитку компанії.

Особливістю українських стартапів є їх гнучкість і здатність швидко адаптуватися до умов ринку. Тому особливо необхідно отримувати фітбек від перших клієнтів. Це дасть змогу якнайшвидше пристосувати та змінити продукт відповідно до потреб користувачів.

Стартапери на етапі «Establishment and growth » повинні остаточно довести проект, послугу, продукт до ідеального стану. Це означає, що бізнес уже повинен генерувати стабільний дохід i забезпечувати клієнтів продукцією. Тобто існує постійно діюча компанія, яка займає місце на ринку і користується популярністю серед споживачів продукту. Паралельно з цим продовжується вкладення грошей у рекламу та інші види просування. На етапі становлення і зростання все ще є потреба у додатковому фінансуванні. Часто інвестори самостійно знаходять цікаві стартапи, аналізують їх та вкладають у них свої кошти саме на третьому етапі. Тому його називають ще «золотим часом» інвестицій. Та, не зважаючи на це, залишаються проблеми фінансування, просування і подальшого розвитку продукту.

Четверта стадія розвитку настає лише за умов стабільного функціонування стартапу. Це стадія розширення. Expantion stage - це такий етап, коли компанія має завершений проєкт/послугу/продукт, який $\epsilon$ 
повнофункціонуючий та приносить постійний прибуток. На стадії розширення відкриваються нові магазини, збільшується асортимент, кількість і якість реклами, відбувається залучення покупців через інтернет, вихід на нові ринки. Розширюючи ринок за рахунок зовнішнього, варто усвідомлюватися, що бізнес-модель прибуткова в Україні, не є гарантією їі ефективності на зовнішніх ринках. Головним ризиком цього етапу $\epsilon$ адекватність прогнозів щодо успішності проекту на нових ринках.

На етапі «Maturity» компанія стабільно працює, по можливості нарощує свої потужності та масштабується. Часто засновники випускають акції компанії з метою залучення додаткових коштів та розширення потужностей виробництва. Можливим $є$ варіант продажу компанії як готового бізнесу.

Сама назва «Етап виходу» говорить про те, що стартап перетворився у бізнес: компанія має високу окупність, займає місце на ринку, має фахову та злагоджену команду і готова далі розвиватися. На цьому етапі інвестори розраховують на отримання дивідендів.

Зважаючи на стадії реалізації стартапу, найважливішою проблемою залишається його фінансування. Серед факторів, що впливають на залучення коштів у проєкт виділимо: крутий продукт (65 \%), перспективи ринку (15\%), ризики середовища (10\%), можливість захисту бізнесу (ТМ, патенти) (7 \%), команда (3\%) (рис. 3).

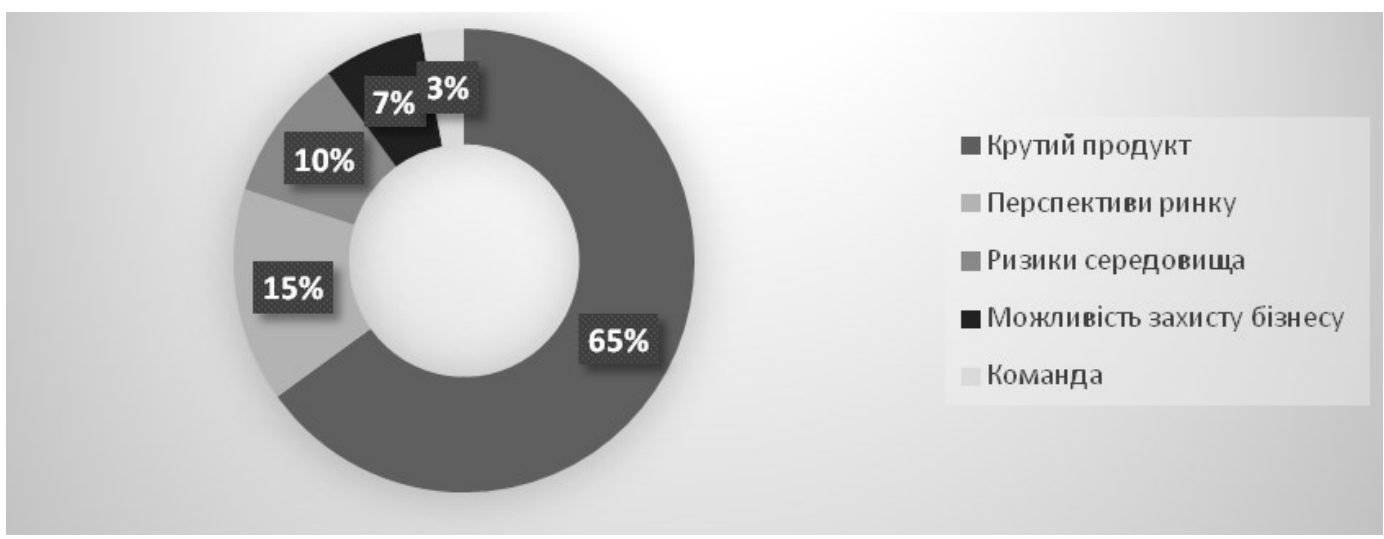

Рис. 3. Фактори, які впливають на залучення коштів у стартап-проекти

Наявність проблем і ризиків реалізації стартапів та враховуючи їх важливість для розвитку сучасної інноваційної моделі розвитку економіки обумовлюють потребу в системній їх підтримці з боку держави [8,9]. Серед основних напрямків такої підтримки виділимо: розвиток культури підприємництва за сприяння закладів освіти; створення сприятливого інвестиційного клімату, насамперед, на засадах стабільності економічної політики; створення законодавчих засад, що регламентують правові, економічні, соціальні аспекти стартапів; інформаційна підтримка, підтримка участі у міжнародних проектах; надання фінансової підтримки з метою активізації підприємництва; посилення соціальної спрямованості стартап-проектів.

\section{Висновки з дослідження і перспективи подальших розвідок у цьому напрямі}

Підсумовуючи, варто зазначити, що світова ніша стартапів швидко розвивається, але при цьому не $\epsilon$ зайнятою, що дає можливість Україні зайняти провідні позиції. У нашої держави є значний потенціал: висококваліфіковані інженерні ресурси, безліч крутих ідей та прагнення до розвитку і втілення бізнесінновацій. Як результат, зростає кількість стартапів, які здобувають визнання на міжнародній арені i отримують фінансування від іноземних інвесторів, підписують угоди про співпрацю з бізнес-ангелами, проходять преакселераційні та акселераційні програми, залучають кошти на краудфандингових платформах та розвиваються у бізнес-інкубаторах. Однак при втіленні задуманого виникають ускладнення, а саме: скрутне фінансове становище; відсутність інформаційної підтримки; несприятливий інвестиційний клімат; низька підтримка з боку держави; недостатній рівень знань у сфері розвитку бізнесу та інші проблеми. Перспективами майбутніх досліджень $є$ пошук новітніх форм фінансування стартапів, реалізація професійного підходу до ведення бізнес-процесів, підвищення ефективності державної політики на ринку стартапів.

\section{Література}

1. Startup Ranking. Countries. URL: https://www.startupranking.com/countries.

2. Іванченко Н.О., Подскребко О.С., Сідлецька А.О. Основні проблеми та перспективи розвитку ринку стартапів в Україні. Бізнес Інформ. 2020. № 9. С. 303-311. URL: https://doi.org/10.32983/2222-44592020-4-303-311

3. Корж А. Україна втратила п'ять позицій у рейтингу країн для відкриття стартапу. Новини. 24.06.2021. URL: https://thepage.ua/ua/news/ukrayina-zajnyala-34-misce-v-svitovomu-rejtingu-startapiv

4. 10 стартапів, що змусили світ говорити про Україну в 2018-му. URL: https://ukrainian./ voanews.com/a/desiat-startapiv-shcho-zmusyly-svit-hovoryty-pro-ukrainu-v-2018/4718865.html 
5. Стартапи в Україні. URL: https://uk.wikipedia.org/wiki/Стартап\#Стартапи_в_Україні.

6. 5 найуспішніших стартапів України. URL: https://ucucfe.lvbs.com.ua/top-5-najuspishnishyhukrayinskyh-startapiv-na-kickstarter/

7. Баб'ячок P.I., Кульчицький I.I. Основні тенденції розвитку стартапів в Україні - проблеми, перешкоди i можливості. URL: https://www.civic-synergy.org.ua/wp-content/uploads/2018/04/Osnovnitendentsiyi-rozvytku-startapiv-v-Ukrayini-1-1.pdf

8. Рудь Н.Т., Богатко Б.В. Стартапи: тенденції розвитку та ризики. Економічний форум. 2/2021, с. 46-54. URL: http://e-forum.Intu.edu.ua/index.php/ekonomichnyy_forum/article/view/203/190

9. Саліхова О.Б., Курченко О.О. Концептуальні засади стратегії розбудови технологоорієнтованих стартапів в інтересах інноваційного розвитку економіки України. Бізнес Інформ. 2020. № 9. C. 65-75. URL: https://www.business-inform.net/article/?year=2020\&abstract=2020_9_0_65_75

\section{References}

1. Startup Ranking. Countries. URL: https://www.startupranking.com/countries.

2. Ivanchenko N.O., Podskrebko O.S., Sidletska A.O. Osnovni problemy ta perspektyvy rozvytku rynku startapiv v Ukraini. Biznes Inform. 2020. № 9. S. 303-311. URL: https://doi.org/10.32983/2222-4459-2020-4-303-311

3. Korzh A. Ukraina vtratyla piat pozytsii u reitynhu krain dlia vidkryttia startapu. Novyny. 24.06.2021. URL: https://thepage.ua/ ua/news/ukrayina-zajnyala-34-misce-v-svitovomu-rejtingu-startapiv

4. 10 startapiv, shcho zmusyly svit hovoryty pro Ukrainu v 2018-mu. URL: https://ukrainian.voanews.com/a/desiat-startapiv-shchozmusyly-svit-hovoryty-pro-ukrainu-v-2018/4718865.html

5. Startapy v Ukraini. URL: https://uk.wikipedia.org/wiki/Startap\#Startapy_v_Ukraini.

6. 5 naiuspishnishykh startapiv Ukrainy. URL: https://ucucfe.lvbs.com.ua/top-5-najuspishnishyh-ukrayinskyh-startapiv-na-kickstarter/

7. Babiachok R.I., Kulchytskyi I.I. Osnovni tendentsii rozvytku startapiv v Ukraini - problemy, pereshkody i mozhlyvosti. URL: https://www.civic-synergy.org.ua/wp-content/uploads/2018/04/Osnovni-tendentsiyi-rozvytku-startapiv-v-Ukrayini-1-1.pdf

8. Rud N.T., Bohatko B.V. Startapy: tendentsii rozvytku ta ryzyky. Ekonomichnyi forum. 2/2021, s. 46-54. URL: http://eforum.Intu.edu.ua/index.php/ekonomichnyy_forum/article/view/203/190

9. Salikhova O.B., Kurchenko O.O. Kontseptualni zasady stratehii rozbudovy tekhnolohooriientovanykh startapiv $\mathrm{v}$ interesakh innovatsiinoho rozvytku ekonomiky Ukrainy. Biznes Inform. 2020. № 9. S. 65-75. URL: https://www.business-inform.net/article/ ?year=2020\&abstract=2020_9_0_65_75

Надійшла / Paper received : 19.10 .2021 Надрукована/Printed : 07.12.2021 